\section{Aaron Sherwood}

Regent College, Vancouver, BC, Canada aaronsherwood1978@gmail.com

ORCID: 0000-0002-2032-1739

DOI: http://dx.doi.org/10.12775/BPTh.2018.020
Biblica

et

Patristica

Thoruniensia

11 (2018) 4: 391-405

ISSN (print) 1689-5150

ISSN (online) 2450-7059

\title{
Still a Neglected Ending: The Grace Benediction of Ephesians 6:24 within the Letter Closing of Ephesians
}

\author{
Wciąż pomijane zakończenie: \\ Błogosławieństwo z Listu do Efezjan 6:24 \\ w zakończeniu Listu
}

\begin{abstract}
Applying J. Weima's model of Pauline letter closings to the conclusion of Ephesians, this article finds that the Grace Benediction of Ephesians 6:24 reflects major concerns of the letter body. As a typical element of a Pauline letter closing, the final element is shaped using atypical features to motivate his audience indirectly yet more forcefully, communicating that they might indeed live as the christocentric people of God by accepting Paul's teachings.
\end{abstract}

Streszczenie. Stosując model J. Weima dotyczący formuł końcowych listów św. Pawła w odniesieniu do zakończenia Listu do Efezjan, autor artykułu zauważa, że występujące na końcu błogosławieństwo upraszające łaskę $(6,24)$ odzwierciedla główne zagadnienia zasadniczej części listu. Owo błogosławieństwo jest wprawdzie typowym elementem zakończenia listu Pawłowego, ale zostało sformułowane przy użyciu nietypowych elementów. Wszystko po to, by pośrednio - choć tym dosadniej - zmotywować odbiorców, dając im do zrozumienia, że oni faktycznie mogą żyć jako Chrystocentryczny Lud Boży, jeśli tylko przyjmą nauczanie Pawła.

Keywords: Grace Benediction; Ephesians; Ephesians 6:24; fictive occasion; letter closing.

Słowa kluczowe: błogosławieństwo upraszające łaskę; Efezjanie; List do Efezjan $(6,24)$; fikcyjny powód; formuła końcowa listu. 


\section{Introduction}

Tn his fairly recent study, Jeffrey Weima analyzes the closings of the undisputed Paulines in light of their ancient background. ${ }^{1}$ Weima demonstrates that in contemporary letter writing, letter closings conventionally include various elements (such as [Final] Greetings and Peace Benedictions), and he is able to track these across Paul's letters of Romans, 1 Corinthians, etc. to show how Paul is a typical ancient letter writer in this respect. But significantly, Weima's analysis further allows him to conclude correctly that part of the reason that Paul's letter closings "exhibit [this] high degree of formal and structural consistency" is so that they might "echo major concerns and themes dealt with in their respective letter bodies"-a proposal that has generally been met well by scholars. ${ }^{2}$

However, the disputed Paulines are beyond the reach of Weima's investigation, which is a pity in the case of Ephesians: The letter closing of Ephesians (6:18-24) is demonstrably conventional in most respects, as regards both ancient and Pauline convention. However, within this (mostly) typical closing, the element of Grace Benediction (v. 24) boasts some rather atypical features that beg looking into. And happily, further investigation bears out for Ephesians Weima's findings, generally, that Pauline letter closings relates to letter content.

In particular, the Grace Benediction of Eph 6:24 is fashioned in a way that causes the letter closing as a whole to reflect the main concerns of Ephesians as a whole. Specifically, Ephesians is concerned throughout with coherence between teaching on who the audience are, and how they therefore ought to live out their identity. Accordingly, the Pauline author (hereafter, 'Paul') 3 intentionally alters especially the typical Pauline Grace Benediction in order that the letter closing offers the audience a final invitation to live out their identity as God's christocentric community of faith.

1 Jeffrey A.D. Weima, Neglected Endings: The Significance of the Pauline Letter Closings (JSNTSup 101; Sheffield: JSOT, 1994); cf. also idem, “The Pauline Letter Closings: Analysis and Hermeneutical Significance," BBR 5 (1995): 177-98.

2 Weima, Neglected, 237; some scholars, however, are not entirely comfortable with Weima's notion of "mirror reading" these final greeting back into their respective letter bodies as substantive "interpretive key[s]" (ad loc., 23).

3 While accepting the disputed status of the Pauline authorship of Ephesians as a document, it is easiest to discuss composition by referring simply to 'Paul,' rather than always speaking of the author of Ephesians who presents him/herself as Paul. See further n. 19, below. 


\section{The Data: Letter Closings and Grace Benedictions in Pauline Documents}

In the course of his examination, Weima shows that the letter closings for the undisputed Pauline letters (and many ancient parallels) generally include the same elements, and usually in a similar order, namely: ${ }^{4}$

- Peace Benediction \& Hortatory Section

- [Final] Greetings:

- greetings

- kiss/reconciliation directive

- autograph

- Grace Benediction

Within this pattern, not all elements are present in the closing of every undisputed Pauline letter-particularly inconsistent are the features of greetings, kiss/reconciliation, and autograph within the element of the [Final] Greeting. As well, the order (and sometimes location) of the Peace Benediction and Hortatory Section are variable. But in general, the pattern holds; and especially the Grace Benediction is nearly always final.

As well, Weima's model helpfully applies to Ephesians:

Eph 6:18-20 Horatory Section

vv. 21-22

[Final] Greetings

V. 21

(impersonal) greeting by way of commendation

v. 22

encouragement

v. 23

Peace Benediction

v. 24

Grace Benediction

Figure 1: The Structural Outline of Ephesians 6:18-24

There is some further detail needed regarding the connection between this letter closing and the foregoing body (see below). But for now, it is enough to note that the ending of Ephesians fits the expected pattern, such that it should be unsurprising if it turns out to do for Ephesians what the closings of the undisputed Paulines do for their letters.

4 See Weima, Neglected, 77-155, esp. the summary on p. 154. Weima offers further details in analysis, showing for instance how the element of Peace Benediction typically includes the features of a transitional introductory element, a divine source, (often) a wish, and (often) a recipient (ad loc., 88-98). 
Further, the last element of the Grace Benediction-that element which is comparatively unusual in Ephesians-generally comprises the elements of a wish, a divine source for its fulfillment, and the recipient of its fulfillment. ${ }^{5}$ Strikingly, the Grace Benedictions across the undisputed Paulines are relatively uniform. But some interesting statistics emerge when the disputed Paulines are further added into the comparison (presented here in [plausible] fictive chronological order): ${ }^{6}$

\begin{tabular}{|c|c|c|c|c|c|}
\hline $\begin{array}{l}1 \text { Thess } \\
5: 28\end{array}$ & ฑ̇ xápıৎ & 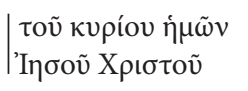 & $\mu \varepsilon \theta^{\prime}$ & $\mid------$ & $\dot{v} \mu \tilde{\omega} v$ \\
\hline $\begin{array}{l}2 \text { Thess } \\
3: 18\end{array}$ & | ’’ xápıç & 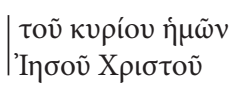 & $\mu \varepsilon \tau \grave{\alpha}$ & $\pi \alpha ́ v \tau \omega \nu$ & v $\dot{\mu} \tilde{\omega} v$ \\
\hline $\begin{array}{l}1 \text { Cor } \\
16: 23-24\end{array}$ & 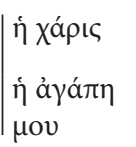 & 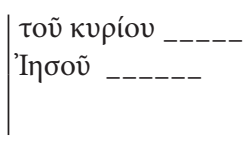 & $\mid \begin{array}{l}\mu \varepsilon \theta^{\prime} \\
\mu \varepsilon \tau \grave{\alpha}\end{array}$ & $\mid \begin{array}{l}------ \\
\pi \alpha ́ v \tau \omega \nu\end{array}$ & $\mid \begin{array}{l}\dot{v} \mu \tilde{\omega} \nu \\
\dot{v} \mu \tilde{\omega} \nu \quad \dot{\varepsilon} \nu \text { X } \rho เ \sigma \tau \tilde{\omega}{ }^{\prime} I \eta \sigma o v\end{array}$ \\
\hline Gal 6:18 & |ं xápıৎ & 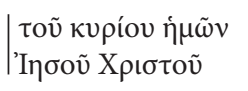 & $\mu \varepsilon \tau \grave{\alpha}$ & 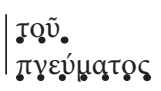 & | \\
\hline $\begin{array}{l}\text { 2 Cor } \\
\text { 13:13 } \\
\qquad \begin{array}{l}\text { kaì } \\
\text { kaì }\end{array}\end{array}$ & 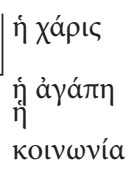 & 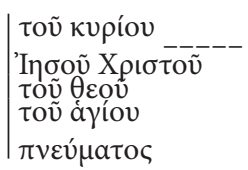 & $\mu \varepsilon \tau \grave{\alpha}$ & $\pi \alpha ́ v \tau \omega \nu$ & $\dot{v} \mu \tilde{\omega} v$ \\
\hline $\begin{array}{l}\text { Rom } \\
16: 20 b\end{array}$ & |̇ xápıৎ & 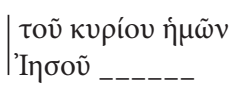 & $\mu \varepsilon \theta^{\prime}$ & $\mid------$ & $\dot{v} \mu \tilde{\omega} v$ \\
\hline Col 4:18c & |̇ xápıৎ & $\mid \begin{array}{l}\text {-------------- } \\
-----\end{array}$ & $\mu \varepsilon \theta^{\prime}$ & -- & $\dot{v} \mu \tilde{\omega} \nu$ \\
\hline Philem 25 & ท̇ xápıs & 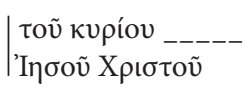 & $\mu \varepsilon \tau \grave{\alpha}$ & 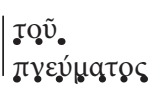 & $\dot{v} \mu \tilde{\omega} \nu$ \\
\hline Eph 6:24 & 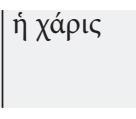 & 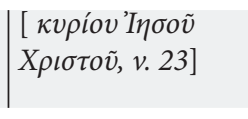 & $\mu \varepsilon \tau \grave{a}$ & $\pi \alpha ́ v \tau \omega \nu$ & 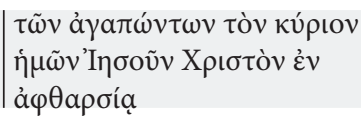 \\
\hline Phil 4:23 & |̇ xápıs & 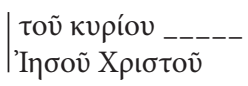 & $\mu \varepsilon \tau \grave{\alpha}$ & 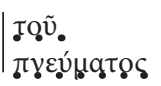 & $\dot{v} \mu \tilde{\omega} \nu$ \\
\hline $\begin{array}{l}1 \mathrm{Tim} \\
6: 21 \mathrm{~b}\end{array}$ & ì xápıs & & $\mu \varepsilon \theta^{\prime}$ & $\mid------$ & | $\dot{v} \mu \tilde{\omega} \nu$ \\
\hline
\end{tabular}

5 Ibidem, 79-83.

6 See also the table in Weima, Neglected, 80. 


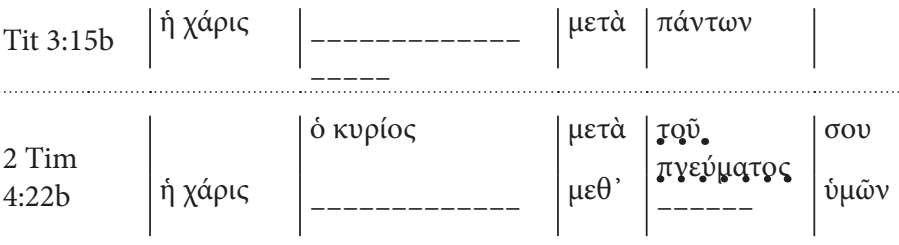

Figure 2: The Grace Benedictions in Pauline Letter Closings

Interestingly, the only fully 'standard' Grace Benediction is that in 2 Thessalonians, which alone contains all the 'correct' features and in the right order (2 Thess 3:18). So it is immediately seen that nearly all of the Grace Benedictions in the Pauline letter closings contain idiosyncratic features. Some of these are more minor, such as slightly incomplete (or altogether missing) verbiage to the component, "of Jesus Christ our Lord" (so 1 Cor 16:23-23; 2 Cor 13:13; Rom 16:20b, etc.; cf. Col 4:18c; 1 Tim 6:21b, etc.). Or larger embellishments are apparent, such as in 2 Cor 13:13 (whose divine source is akin to a protoTrinitarian reference; see also 1 Cor 16:23-24; 2 Tim 4:22b). Or again, there is a set that refers not just to the audience but to their spirit (Gal 6:18; Philem 25; Phil 4:23; 2 Tim 4:22b).

But in some ways perhaps the greatest standout is Eph 6:24. The Grace Benediction in the letter closing of Ephesians is in the third person, and ostensibly not addressed to the letter audience. As well it is most noticeably embellished, where grace is not just wished upon 'you' (or even upon 'them'), but upon "those who love our Lord Jesus Christ with an imperishable [love]." And finally, the role of Eph 6:24 is further complicated by the unclear nature of how the letter closing in which it sits relates to the letter body.

So, the questions of how the close of Ephesians is structured and of how it relates the preceding material come to the fore in the wording in v. 24, name-

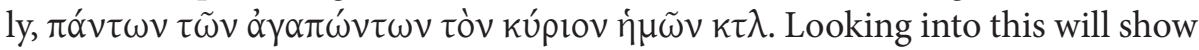
how Eph 6:24 and the letter closing indeed complement the content of the letter as a whole. Accordingly, the next steps in clarifying the situation are first to examine the shape and position of the letter closing in Ephesians; and second to recall what are central theme(s) in the letter with which the closing might resonate.

7 Otherwise, Ephesians is notably the only disputed Pauline whose Peace Benediciton matches those of the undisputed letters; cf. Charles H. Talbert, Ephesians and Colossians (Paideia; Grand Rapids: Baker, 2007), 171, even in conversation with Weima. 


\section{The Letter Closing of Ephesians 6:18-24}

Scholars are nearly unanimous that Eph 6:23-24 partly constitute the letter closing, such that the odd features of v. 24 makes it worthy of special attention. ${ }^{8}$ (Just as v. 24 is clearly the Grace benediction, v. 23 is itself the Peace Benediction that also helps to close the letter.) But before even getting to the puzzling wording of v. 24, there are some preliminary issues that need considering.

First is the issue of the slightly unintuitive character of the Hortatory Section in vv. 18-20 (see Fig. 1, above). It could be argued that 6:18-20 does not begin to the letter closing, so much as conclude the pericope of $6: 10-20$ and with it conclude the paraenesis of the letter body, based on the ambiguous grammatical relationship between vv. 18-20 and the rest of 6:10-17. But really, that ambiguity in v. 18 is somewhat common to the style of Ephesians, generally (see further below).

Specifically, the grammatical ambiguity here is caused by the lack any indicative vb. in vv. 18-20, begging the question as to what the ptc.s $\pi \rho \circ \sigma \varepsilon v \chi$ ó $_{\mu \varepsilon v o l}$ and à $\gamma \rho v \pi v o \tilde{v} v \varepsilon \varepsilon$ are subordinate. Of the two contested views, one is that these ptc.s are dependent upon the impv. $\sigma \tau \tilde{\eta} \tau \varepsilon$ in v. 14 (alongside the likewise dependent impv. $\delta \varepsilon \dot{\varepsilon} \xi \alpha \sigma \theta \varepsilon$, in v. 17a), such that the audience are instructed to "stand... by praying... and by being alert" (and also in v. 17 "by taking up the helmet of salvation"). On this interpretation, all of vv. 14b-20 is together an expansion upon how the audience are to "stand" in spiritual warfare. ${ }^{9}$ The second main view sees the ptc. in vv. $18-20$ as subordinate instead to $\delta \varepsilon ́ \xi \alpha \sigma \theta \varepsilon$, in v. 17a. On this interpretation, vv. 17-20 are thought to somehow parallel vv. 14-16,

8 The lone exceptions who prove the rule are Andrew T. Lincoln, Ephesians (WB 42; Dallas: Word, 1991), 463, who concedes that at least 6:21-24 contain the features typical of Pauline letter closings, but still somehow asserts that both vv. 21-22 and vv. 23-24 have "little relationship to the rest of the letter"; and Peter T. O'Brien, The Letter to the Ephesians (Pillar New Testament Commentary; Grand Rapids: Eerdmans, 1999), 494, who overlooks the odd phraseology of v. 24 by glossing it as a general statement that believers submit gladly to a loving Christ.

9 See e.g. F.F. Bruce, The Epistles to the Colossians, to Philemon and to the Ephesians (NIBCNT Grand Rapids: Eerdmans, 1984), 409-412; Lincoln, Ephesians, 450-452; Ernest Best, A Critical and Exegetical Commentary on Ephesians (ICC; Edinburgh: T\&T Clark, 1998), 604; and O'Brien, Letter, 480 n. 178, 483; W.J. Larkin, Ephesians: A Handbook on the Greek Text (Baylor Handbook on the Greek New Testament; Waco: Baylor University Press, 2009), 163. 
with the audience being commanded in vv. 17ff. to "take up the helmet... by praying... and by being alert." ${ }^{\prime 0}$

In either case, however, Andrew Lincoln rightly concludes that even if "as regards syntax, vv 18-20 are clearly joined to what has preceded," still this entire ending section is together set apart and distinct in terms of content. ${ }^{11}$ Similarly, Frank Thielman is correct to complain that interpreting 6:18-20 just in terms of what precedes as "the syntax would demand" wrongly forces the author's meaning to be that believers should receive salvation and God's word by means of praying and watching; on the contrary, in these verses the point is that "a simple and straightforward focus on the need for prayer replaces the military imagery." ${ }^{12}$ Furthermore, interpreters often readily recognize that the believers-as-miniature-divine-warriors-in-miniature metaphor only extends as far as v. 17, and at the very least vv. $18 \mathrm{fff}$. apply that metaphor in concrete terms to the audience.

Altogether, then, v. 18 is attached to either v. 14 or v. 17 (as advanced in one or the other grammatical disambiguation's proposed above), but at the same time - in something of a hinge device-vv. 18-20 non-formally constitutes the Hortatory Section of the overall letter closing. In connection with (and segueing from) the miniature-divine-warriors metaphor, the audience are to continuously praying and keeping watch over God's activity in their midst. ${ }^{13}$ The upshot is that the content both marks off vv. 18-20 as an Hortatory Section;

10 The proponents of this view generally fail to agree upon (or often even to account for) a coherent theme for esp. vv. 17-20, beyond perhaps something about prayer being generically foundational to spiritual warfare; see e.g. Harold W. Hoehner, Ephesians: An Exegetical Commentary (Grand Rapids: Baker, 2001), 848-849 (who argues strongly that the initial kai of v. 17 decisively shows the structure of vv. 14-20 to be one of stand and receive, albeit without giving either portion extensive elaboration); Rudolf Schnackenburg, Ephesians: A Commentary (trans. Helen Heron; Edinburgh: T\&T Clark, 1991), 267, 279; Talbert, Ephesians, 166; Ben Witherington III, The Letters to Philemon, the Colossians, and the Ephesians: A Socio-Rhetorical Commentary on the Captivity Epistles (Grand Rapids: Eerdmans, 2008), 353-354; Gerhard Sellin, Der Brief an die Epheser (KEK 8; Göttingen: Vandenhoeck \& Ruprecht, 2008), 485.

11 Ephesians, 430, sic.

12 Ephesians (BECNT; Grand Rapids: Baker, 2010), 433.

13 That vv. 18-20 are offset is further seen in how a majority of commentators and numerous ETs (cf. NEB, NASB, NIV, NRSV, ESV, TNIV, NET, etc.) acknowledge that the best way of dealing with the style of Ephesians as it occurs in v. 18 is by translating its ptc.s imperativally, i.e., 'Through every prayer and request, pray at all times...[and] be alert...' The suggestion in Thielman, Ephesians, 433 is attractive, that vv. 18-20 are a new notion or

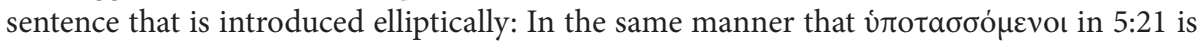
a new imperatival thought that was related to but has shifted away from $\pi \lambda \eta \rho \circ \tilde{\sigma} \sigma \theta \varepsilon$ in $5: 18$, 
and it makes taking 6:18-24 as an effectively independent thought unit (i.e. the letter closing) the most sound way of treating the text.

The next puzzle regarding 6:18-24 is how vv. 20-21 do not strictly constitute a greeting. Nevertheless, these verses clearly sit in the place were the [Final] Greeting element typically falls in Pauline letter closings (above). And vv. 2021 do work as a rough greeting - what Thielman suggests calling a "concluding commendation"14_-since references to (concern over) knowing of Paul's circumstances to chiastically surround (vv. 21a and 22b) a central emphasis on Tychicus and his mission of informing the audience (vv. 21b-22a). ${ }^{15}$ And really, given the impersonal nature of Ephesians in general (see below), fashioning vv. 20-21 into a concluding commendation of Tychicus as Paul's emissary is as close as the letter closing could get to a [Final] Greeting.

The last asynchronous feature of 6:18-24 (besides the distinct nature of v. 24 itself), is how the Peace Benediction (v. 23) is unusually preceded by the [Final] Greeting (vv. 21-22). But in this, the author is evidently exercising a bit of stylistic freedom in order that the letter closing accommodates the particular rhetoric of Ephesians in general. ${ }^{16}$ In the case of Eph 6:18-24, the Peace Benediction is penultimate and directly placed up against the ultimate Grace Benediction to fittingly re-emphasize the motif of peace that is so pronounced throughout the letter. ${ }^{17}$

So, taking into account the function of vv. 18-20, the nature of vv. 21-21 and the suitable placement of v. 23, Eph 6:18-24 is an organic, occasionally appropriate combination of both the letter closing itself, and the transition from

in 6:18 the author effectively and "somewhat enigmatically begins a new thought"; cf. John Muddiman, The Epistle to the Ephesians (BNTC; New York: Continuum, 2001), 295.

14 Ephesians, 438.

15 That vv. 20-21 really do connect Paul and his audience (regardless of a possible literary relationship to Col 4:7-8) is further highlighted by Talbert, Ephesians, 20-25, who notes that the ancient conventions of benefaction and reciprocity include the beneficiaries' obligation of continued loyalty to their benefactor (cf. David E. Briones, Paul's Financial Policy: A Socio-Theological Approach [LNTS 494; New York: T\&T Clark, 2013]), which comes up here in v. 20 in terms of the audience's support of Paul as the divine benefactor's ambassador who speaks throughout on God's behalf; cf. Martin Kitchen, Ephesians (New Testament Readings; London: Routledge, 1994), 127.

16 It would be unreasonable to speculate instead that this displacement results from a pseudepigrapher's inability to exactly reproduce the typical format of Pauline letter closings.

17 As Weima, Neglected, 153 points out, the elements in Pauline letter closings of Peace- and Grace Benedictions are mirrored in the Greetings of grace and peace in the letter openings, forming an inclusio in the start and end of each letter-especially so in the case of Ephesians; cf. O’Brien, Letter, 492; Witherington, Letters, 358, etc. 
the letter body into that closing. The last thing to consider before seeing how the Grace Benediction of 6:24 uniquely contributes to the effectiveness of the letter closing, is to note the motif(s) of the letter that v. 24 also reflects.

\section{Background to the Grace Benediction in Ephesians 6:24}

Scholars have long recognized that Ephesians exhibits a comparatively impersonal style, and is rather didactic in its structure. ${ }^{18}$ As well, there is consensus that, broadly speaking, the letter occasion is that the audience (Gentile believers in Asia Minor) are experiencing some manner of spiritual oppression, and so Paul (the purported author) writes them to provided the needed reminder (and/or teaching) that their identification with Christ has lifted them above such oppression. ${ }^{19}$ In particular, although the historical destination of Ephesians remains debated, the best explanatory model is arguably that the letter is a circular(/encyclical) or regional letter, directed toward churches in the Lycus Valley region, which would entirely explain the dearth of personal references between Paul and his audience. ${ }^{20}$

18 See Lincoln, Ephesians, xl-xli; R.P. Martin, "Reconciliation and Unity in Ephesians," RevExp 93 (1996): 203; Best, Ephesians, 61; Hoehner, Ephesians, 77 (who observes how the blending of styles and genres in Ephesians is typical of all the Pauline documents), etc. For an introduction to occasion, audience and literary structure in Ephesians, see Aaron Sherwood, Paul and the Restoration of Humanity in Light of Ancient Jewish Traditions (AJEC 82. Leiden: Brill, 2013), 247-250.

19 The author both presents him/herself and is accepted by the audience as Paul. So even though the authenticity of the letter remains debated, it makes sense methodologically to analyze the text using its own fictive presentation, speaking of authorial intention in terms of the aims that "Paul" has within the presentation of the letter. There is consensus that one plausible explanation for the impersonal character of Ephesians relates to a pseudepigrapher's inability to fabricate enough personal details to display for his/her anachronistic fictive audience; but equally, the other model recognized as plausible by scholars is that the author (whether Paul or a deutero-Pauline writer) writes to believers in a region rather than just one church community (so Lincoln, Ephesians, pp. 462-463; Best, Critical, p. 613; Hoehner, Ephesians, pp. 867-868; Thielman, Ephesians, p. 438, etc.); see below.

20 Though not all scholars agree, perhaps the best explanation is offered by Clinton E. Arnold, The Colossian Syncretism: The Interface between Christianity and Folk Religion at Colossae (WUNT 2/77; Grand Rapids, MI: Baker, 1995), who makes the case that the Lycus Valley faced a mixing of folk superstitions and Christian beliefs (contra L. Joseph Kreitzer, The Epistle to the Ephesians (Epworth; London: Epworth, 1997), 48; Muddiman, Epistle, 20-32); see sherwood, Paul's, 248-249 n. 88. 
Then, there is to consider the literary structure of Ephesians, and how it intersects the letter theme(s). And here, some version of the scholarly consensus is also correct, that Eph 1-3 generally focuses upon teaching, while chs. 4-6 generally focus upon paraenesis. Further, within chs. 1-3, ch. 2 in particular aims at teaching the audience that they are those whose identity is fundamentally defined by their relationship with Christ. ${ }^{21}$ Specifically, the overriding motif in ch. 2 is that the audience are unified and enjoy shalom as God's eschatological community of faith as a result of their identification with Jesus. ${ }^{22}$ In turn, this shapes the overall focus of chs. 1-3 as a larger literary unit, in that the audience (as God's eschatological people in Christ) participate with Christ in the defeat of the hostile cosmic forces who are causing their experience of oppression, namely, the principal (fictive) occasion for Ephesians having been written in the first place. ${ }^{23}$ Correspondingly, scholars generally recognize the corollary in the ethics in chs. 4-6, namely, the unifying theme of the audience's unity, and their participation in the community of faith's growth and new life.

The inherent tension in the audience's circumstances comes from the commonplace within Graeco-Roman culture that a person's identity is demonstrated by what she does. Paul identifies his audience as Christians, but there is a danger that they may not be really living as Christians, since they do not seem to be rising with Christ above the powers that assail them, and perhaps because (as a result) they struggle to live with each other in a christlike and harmonious fashion. But Ephesians does not therefore repudiate the audience's Christian identity. Instead, in terms of fictive setting, Paul reminds (and/or teaches) them what is the true nature and relevance of their identity (chs. 1-3), and then urges them to catch up with it in how they live (chs. 4-6). The letter is thus literarily structured to encourage Paul's audience to live faithfully out their identity, thereby releasing the tension since who they are will then indeed be evident in what they do.

So, taking into account both occasion and the non-localized nature of the audience, it seems that a central concern for the author of Ephesians is whether the audience will buckle under the spiritual oppression that they face, and not live out (and/or exhibit) their identity as God's christocentric people. The au-

21 The best estimation is that of O'Brien, Letter, 66; Hoehner, Ephesians, 73, both of whom analyze 1:3-3:21 as the letter body, comprising a berakah (1:3-14), a Thanksgiving and Prayer (1:15-23), teaching (ch. 2), and the resumption and doxological close of the thanksgiving and prayer $(3: 1,14-21$, interrupted by the digression of 3:2-13).

22 See further Sherwood, Paul's, 249-259.

23 Cf. Sherwood, "Paul's Imprisonment as the Glory of the Ethnē: A Discourse Analysis of Ephesians 3:1-13,” BBR 22 (2012): 97-112. 
thor crafts message to be impersonal since his audience are several communities and not just one, and he wants his teaching and instruction to apply equally to them all. But as written, the letter presents Paul's effort to help all those for whom the letter is intended face the hazard of not living out their peace, their unity or their identity as those who follow God in Jesus Christ. And this goes a long way toward answering the question of why the Grace Benediction in 6:24 looks the way that it does.

\section{The Grace Benediction in Light of the Occasion, Audience and Literary Structure of Ephesians}

The two especially standout components of the Grace Benediction in Eph 6:24 are that it is delivered in the third person (instead of the second person), and that it uses the distractingly unconventional language of "those who love our Lord Jesus Christ with an imperishable [love]." The third person address actually begins in v. 23 (the Peace Benediction, above) when the author wishes "peace to the brethren," with vv. 23 and 24 being coordinated. As well, the language

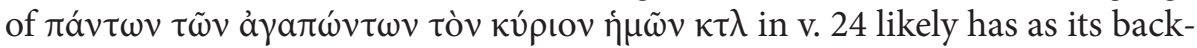
ground the expression "those who love God" in some biblical and post-biblical traditions (LXX Exod 20:6; LXX Deut 5:10; 7:9; Pss. Sol. 4.25; 1 En. 108:8; Rom 8:28, etc.). However, most attempts to look into Eph 6:24 are limited to these observations. So while most scholars may agree that such features make examining Eph 6:24 worthwhile, ${ }^{24}$ so far their attempts to do so are found wanting.

The shift to third person in Eph 6:24 (and v. 23) does relate to the general impersonal character of the letter (due to its wide audience and likely nature as a circular/encyclical), but that does not tell the whole story. ${ }^{25}$ In fact, the other Pauline instances of such a shift in person in a letter closing is Galatians 6:16

24 See n. 8, above.

25 E.g. Andreas Zurich Lindemann, Der Epheserbrief (ZBK; Zurich: Theologischer, 1985), 118; Schnackenburg, Ephesians, 289-291; Lincoln, Ephesians, 465; Best, Critical, 613; Witherington, Letters, 357; Sellin, Brief, 494 all dismiss the shift to third person but this way, without much further warrant or investigation. Numerous scholars rightly reject the simplicity of this approach because the author is comfortable using the second person up through 6:22, but at the same time they generally fail in giving a positive account for the shift; see e.g. Bruce, Epistles, 415; O’Brien, Letter, 493-494; Clinton E. Arnold, Ephesians (Zondervan Exegetical Commentary on the New Testament 10; Grand Rapids: Zondervan, 2010), 481 (who uncommonly attempts to address the phraseology of v. 24 by claiming that it somehow emphasizes the personal relationship that exists between believers and Christ; ad loc., 482); Thielman, Ephesians, 445. 
(there the Peace Benediction), where the shift results from conflict between Paul and his audience. ${ }^{26}$ That is, the other time that a Pauline author uses the third person in his letter closing, he does so specifically so that the closing reflects and reiterates a major theme of the letter content. This provides warrant for searching for the same phenomenon also in Eph 6:[23-]24.

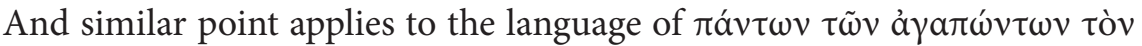
$\kappa v ́ p ı v ~ \eta \mu \tilde{\omega} \nu \kappa \tau \lambda$ in v. 24. It will not do to leave interpretation of this language to the observation of a connection to the expression elsewhere "those who love God." ${ }^{27}$ Such a background may help to explain the fact of the form of Eph 6:24, but it does not explain why that language is so distinctively put to use in the Grace Benediction in Ephesians. Significantly, in such relevant traditions (above), the expression "those who love God" refers to those who sacred traditions authoritatively identify God's people in terms of their faithful, exclusive devotion to Yhwh. So if anything, such an echo in 6:24 points to the importance of the connection between the theme(s) of Ephesians and the Grace Benediction. Specifically, the language of "those who love our Lord Jesus Christ with an imperishable [love]" apparently makes Eph 6:24 into a christological adaptation of what would usually be reference to theocentric identity. And in turn, this affects how the letter closing (of which the Grace Benediction is one element) intersects with presentations throughout Ephesians of the audience as the eschatological, christocentric community of faith belonging to Israel's God, Yhwh.

\section{Conclusions}

Taking all this together, and bearing in mind the occasion, audience and literary structure of the letter, the address in the third person and the distinctive language of "those who love our Lord Jesus" together reveal the purpose to the shape of Eph 6:24. The author composes the Grace Benediction in 6:24 so that the letter closing will address the rhetorical worry that the audience could miss out on being those who receive peace (i.e., those who love the Lord). This tactic becomes apparent when all the evidence noted so far is looked at together:

The author takes the component that would normally appear in the Grace

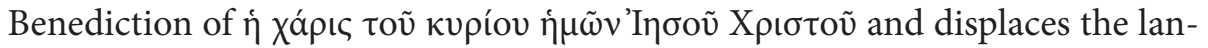
guage forward (to the Peace Benediction in v. 23) to ensure that "Lord Jesus

26 Cf. Lincoln, Ephesians, p. 465.

27 So Lincoln, Ephesians, 466; Best, Critical, 619; Hoehner, Ephesians, 874 (following Schlier); Thielman, Ephesians, 445, etc. 
Christ" is doubly prominent in the letter closing. And then correspondingly, the author conspicuously inserts into v. 24-the last verse of the letter and of the letter closing-an innovated christological version of a not uncommon theocentric designation for God's people. As a consequence, this iteration of the Grace Benediction downplays how Christ is the source of grace, and (in comparison) focuses more upon how the "those" are the recipients of said grace. ${ }^{28}$ Such language indicates that Paul is concerned that not all among his audience may necessarily persist in devotion to Christ when facing the occasional difficulties that originally prompted his correspondence (leaving aside potential implications for christology and ecclesiology in Ephesians) ${ }^{29}$ Furthermore, the form of Grace Benediction (and Peace Benediction) means that 6:[23-]24 is the element(s) of the letter closing relating to grace and peace. And notably, in Ephesians grace and peace particularly are together both the binding agent throughout letter content, and what makes that content occasionally relevant for the original audience of the letter. Finally, even though v. 24 is clearly directed at the audience, the use of the third person in v. 24 (and v. 23) rhetorically acknowledges the potential danger of a (theological) disjunction between Paul's audience and the recipients of the Grace Benediction.

These data all come together to dictate how 6:24 wants to be interpreted. Namely, in 6:24, the author uses the third person and trades out the standard

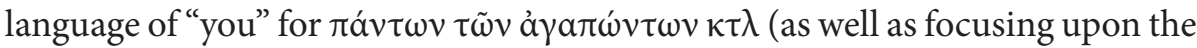
"those who") in order to have Paul step back, stand alongside his audience, and rhetorically present them with a portrait of the people who receive victory over the powers that afflict the audience, and who also receive the shalom amongst themselves and with God. Vitally, they are that category of people whose victory and shalom are precisely identify them as God's people in Christ. That the

28 Cf. Thielman, Ephesians, p. 445.

29 The role of $\dot{\varepsilon} v a \dot{\alpha} \varphi$ $\theta \rho \sigma i$ (the final prep. phrase of v. 24) may correlate with this proposed impact for $\pi \alpha \dot{v} \tau \tau \omega \nu \tau \tilde{\omega} \nu \alpha \dot{\alpha} \gamma \alpha \pi \dot{\omega} v \tau \omega \nu \kappa \tau \lambda$, even though the syntax is not unambiguous.

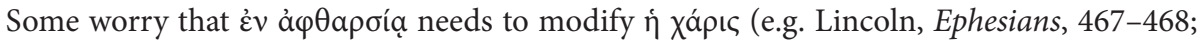
O'Brien, Letter, 495; Margaret Y. MacDonald, Colossians and Ephesians [SP; Collegeville, MN: Liturgical, 2008], 352) so that a reading of 'with an undying love' is not allowed to imply that grace is conditional according to v. 24. But such an implication is not inevitable, and

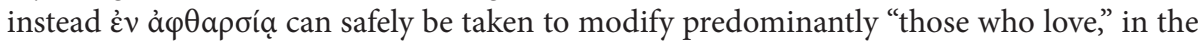
sense of attaching primarily to the those as a characterization of them (rather than a literal quantification of their love itself; so Thielman, Ephesians, 447-448, comparing Eph 6:24 and Pss. Sol. 6.6; cf. e.g. Bruce, Epistles, 416; Hoehner, Ephesians, 877; see Lincoln, Ephesians, 467-468 for a bibliography). So overall (and in any case), ’̉v à $\varphi \theta \alpha \rho \sigma i ́ a$ accentuates that by some combination of God's(/Christ's) grace and/or the audience's love, the relationship between Christ and the "those" of v. 24 is meant to be everlasting in its character. 
author presents this portrait in the third person does not entail that the audience are not this people. Rather, his language is pointedly meant to show the audience that their actually being and living as "those" who genuinely are God's eschatological, christocentric people is what us at stake in 6:[23-]24.

In this way, the Grace Benediction and so also the letter closing in Ephesians both advance the author's communicative strategy for the letter. As his final word, the author hold up to his audience an ideal portrait of themselvesand of who they ought to be-as a means of rhetorically inviting them to match that portrait, to be the brethren. In short, to be the "those" of whom vv. 23-24 speaks. This atypical version of a typical element of a Pauline letter closing thereby motivates the audience to live out both the theology (chs. 1-3) and the instruction (chs. 4-6) that Paul presents to them throughout Ephesians.

Therefore, the Grace Benediction in Eph 6:24 brings the letter closing to reflect a pivotal theme-if not the main theme-of the letter. Namely, Eph 6:24 marries with Paul's calling his audience to live out their identity. As the Grace Benediction confirms and urges, they are those who have received grace, and those whose love for Jesus, the Lord and Messiah of all believers, corresponds to their actions, their lifestyle, and their informed conviction that they share in Jesus' defeat of all opposing spiritual powers.

\section{References}

Arnold, Clinton E. The Colossian Syncretism: The Interface between Christianity and Folk Religion at Colossae. WUNT 2/77. Grand Rapids: Baker, 1995.

Arnold, Clinton E. Ephesians. Zondervan Exegetical Commentary on the New Testament 10. Grand Rapids: Zondervan, 2010.

Best, Ernest. A Critical and Exegetical Commentary on Ephesians. ICC. Edinburgh: T\&T Clark, 1998.

Briones, David E. Paul's Financial Policy: A Socio-Theological Approach. LNTS 494. New York: T\&T Clark, 2013.

Bruce, F.F. The Epistles to the Colossians, to Philemon and to the Ephesians. NIBCNT. Grand Rapids: Eerdmans, 1984.

Hoehner, Harold W. Ephesians: An Exegetical Commentary. Grand Rapids: Baker, 2001. Kitchen, Martin. Ephesians. New Testament Readings. London: Routledge, 1994.

Kreitzer, L. Joseph. The Epistle to the Ephesians. Epworth; London: Epworth, 1997.

Larkin, W.J. Ephesians: A Handbook on the Greek Text. Baylor Handbook on the Greek New Testament. Waco: Baylor University Press, 2009.

Lincoln, Andrew T. Ephesians. WB 42. Dallas: Word, 1991.

Lindemann, Andreas Zurich. Der Epheserbrief. ZBK. Zurich: Theologischer, 1985. 
MacDonald, Margaret Y. Colossians and Ephesians. SP. Collegeville, MN: Liturgical, 2008.

Martin, R.P. "Reconciliation and Unity in Ephesians." RevExp 93 (1996): 203-235.

Muddiman, John. The Epistle to the Ephesians. BNTC. New York: Continuum, 2001.

O'Brien, Peter T. The Letter to the Ephesians. Pillar New Testament Commentary. Grand Rapids: Eerdmans, 1999.

Sellin, Gerhard. Der Brief an die Epheser. KEK 8. Göttingen: Vandenhoeck \& Ruprecht, 2008.

Schnackenburg, Rudolf. Ephesians: A Commentary. Translated by Helen Heron. Edinburgh: T\&T Clark, 1991.

Sherwood, Aaron, Paul and the Restoration of Humanity in Light of Ancient Jewish Traditions. AJEC 82. Leiden: Brill, 2013.

Sherwood, Aaron. "Paul's Imprisonment as the Glory of the Ethnē: A Discourse Analysis of Ephesians 3:1-13." BBR 22 (2012): 97-112.

Talbert, Charles H. Ephesians and Colossians. Paideia. Grand Rapids: Baker, 2007.

Thielman, Frank. Ephesians. BECNT. Grand Rapids: Baker, 2010.

Weima, Jeffrey A.D. Neglected Endings: The Significance of the Pauline Letter Closings. JSNTSup 101; Sheffield: JSOT, 1994.

Weima, Jeffrey A.D. "The Pauline Letter Closings: Analysis and Hermeneutical Significance." BBR 5 (1995): 177-198.

Witherington Ben III, The Letters to Philemon, the Colossians, and the Ephesians: A Socio-Rhetorical Commentary on the Captivity Epistles. Grand Rapids: Eerdmans, 2008. 